Jurnal Pendidikan Dasar PerKhasa

Volume 4, Nomor 2, Oktober 2018

\title{
ANALISIS PENGARUH PEMBELAJARAN QUANTUM TERHADAP PROSES DAN HASIL BELAJAR SISWA PADA MATA PELAJARAN IPA KELAS VA DI SDN JOGLO 04 PETANG (studi pre-eksperimen)
}

\author{
Anita Dewi, Ratnawati Susanto \\ Pendidikan Guru Sekolah Dasar, FKIP, Universitas Esa Unggul \\ Jalan Arjuna Utara No 9, Jakarta Barat 11610, Indonesia \\ email: anitadewi2896@yahoo.com, ratnawati@esaunggul.ac.id
}

\begin{abstract}
The purpose of this research is to find out whether there is a influence of quantum learning on the process and student learning outcomes in science subjects in class $V$. This research is a quantitative study using the One-Group Pretest-Posttest method. Determination of the number of samples is determined using the Slovin formula and obtained a sample of 30 respondents. Data collection techniques in this study use questionnaires. The results of testing the first hypothesis of the partial test (t test) obtained $\mathrm{t}$ count $=4.123>\mathrm{t}$ table $=2.048$ with a significance of $0.000<0.05$. These results show a significant tcount, so Ho is rejected and accepted $\mathrm{H} 1$ which means there is a positive and significant influence between quantum learning on the learning process of students. The results of testing the second hypothesis with a partial test (t test) obtained thitung $=6.873>$ $\mathrm{t}$ table $=2.048$ with a significance of $0.000<0.05$. This result shows that $\mathrm{t}$ count is significant so $\mathrm{Ho}$ is rejected and accepted $\mathrm{H} 1$ which means there is a positive and significant influence between quantum learning on student learning outcomes. Based on these data means that the variables of quantum learning have a positive and significant effect on the variables of process and learning outcomes.
\end{abstract}

Keywords: Quantum Learning, Learning Process, Learning Outcomes

Abstrak: Tujuan penelitian ini adalah untuk mengetahui apakah terdapat pengaruh pembelajaran quantum terhadap proses dan hasil belajar siswa pada mata pelajaran IPA di kelas V. Penelitian ini merupakan penelitian kuantitatif dengan menggunakan metode One-Group Pretest-Posttest. Penentuan jumlah sampel ditentukan menggunakan rumus Slovin dan diperoleh sampel sebesar 30 responden. Teknik pengumpulan data pada penelitian ini menggunakan angket. Hasil pengujian hipotesis pertama uji parsial (uji t) diperoleh $t_{\text {hitung }}=4,123>t_{\text {tabel }}=2,048$ dengan signifikansi $0,000<0,05$. Hasil ini menunjukkan $t_{\text {hitung }}$ signifikan, sehingga $\mathrm{H}_{\mathrm{o}}$ ditolak dan terima $\mathrm{H}_{1}$ yang artinya terdapat pengaruh positif dan signifikan antara pembelajaran quantum terhadap proses belajar peserta didik. Hasil pengujian hipotesis kedua dengan uji parsial (uji $\mathrm{t}$ ) diperoleh $\mathrm{t}_{\text {hitung }}=$ $6,873>t_{\text {tabel }}=2,048$ dengan signifikansi $0,000<0,05$. Hasil ini menunjukkan $t_{\text {hitung }}$ signifikan sehingga $\mathrm{H}_{0}$ ditolak dan terima $\mathrm{H}_{1}$ yang artinya terdapat pengaruh positif dan signifikan antara pembelajaran quantum terhadap hasil belajar peserta didik. Berdasarkan data tersebut berarti variabel pembelajaran quantum berpengaruh positif dan signifikan terhadap variabel proses dan hasil belajar.

Kata Kunci : Pembelajaran Quantum, Proses Belajar, Hasil Belajar

\section{Pendahuluan}

Pembelajaran adalah proses

kegiatan belajar mengajar yang dilakukan oleh guru dan peserta didik dalam situasi tertentu untuk mencapai tujuan 
pembelajaran yang telah ditetapkan. Di dalam pembelajaran terdiri dari dua subjek yaitu guru dan peserta didik dimana guru harus dapat mengelola dan membimbing peserta didik dalam proses pembelajaran. Sedangkan peserta didik dilibatkan melalui interaksi yang diciptakan selama proses pembelajaran. Peserta didik dapat berpartisipasi dengan baik dalam proses pembelajaran apabila suasana saat proses pembelajaran menggembirakan dan menyenangkan sehingga fokus peserta didik selama proses pembelajaran dapat dipusatkan pada materi yang disampaikan dengan begitu proses pembelajaran dapat berjalan dengan efektif. Dalam menciptakan proses pembelajaran yang efektif tidaklah mudah karena dalam proses pembelajaran seorang guru harus mampu memusatkan fokus peserta didik terhadap materi yang diberikan dengan perbedaan karakter individu yang dimiliki setiap peserta didik dan tingkat kesiapan belajar peserta didik yang berbeda. Dalam proses pembelajaran metode pembelajaran yang digunakan harus dapat bervariasi. Namun pada kenyataannya masih terdapat guru yang belum memperhatikan hal-hal tersebut sehingga proses pembelajaran kurang efektif.
Proses pembelajaran yang kurang efektif dapat mempengaruhi hasil belajar peserta didik karena guru yang baik adalah guru yang mampu memanfaatkan sumber belajar sesuai dengan kebutuhan peserta didik.

Berdasarkan dari hasil studi pendahuluan yang dilakukan di SDN Joglo 04 Petang tahun ajaran 2017/2018 diketahui bahwa hasil belajar yang dimiliki oleh peserta didik di SDN Joglo 04 Petang pada mata pelajaran IPA masih dalam kategori rendah karena tingkat ketuntasan pada rentang 40\%-48\% dari batas ketuntasan $80 \%$ Sesuai dengan Kurikulum Tingkat Satuan Pendidikan (KTSP) yang ditetapkan di SDN Joglo 04 Petang. Tingginya presentase nilai ulangan harian mata pelajaran IPA di SDN Joglo 04 Petang yang tidak tuntas menandakan dalam pelaksanaan proses pembelajaran yang dilaksanakan oleh guru dikelas cenderung monoton dan membosankan. Hal ini di latar belakangi oleh guru yang belum sepenuhnya melaksanakan pembelajaran yang berpusat pada peserta didik (student centered). Sehingga peserta didik cenderung lebih pasif dalam proses pembelajaran membuat kurangnya pemahaman yang dimiliki oleh peserta didik terhadap materi yang disampaikan. 
Analisis Pengaruh Pembelajaran Quantum...

Dalam kondisi demikian yang menjadikan alasan utama dalam menuntaskan permasalah tersebut perlu dilakukan perubahan mendasar agar dapat membantu mengembangkan potensi yang dimiliki peserta didik. Perubahan mendasar tersebut meliputi perubahan strategi dan model pembelajaran yang bervariasi untuk digunakan dalam proses pembelajaran sehingga suasana yang terwujud dalam proses pembelajaran tersebut bukanlah suasana yang menegangkan melainkan suasana proses pembelajaran yang menyenangkan. Model pembelajaran yang inovatif dan efektif merupakan hal penting dalam meningkatkan keberhasilan pembelajaran karena model pembelajaran melihat kebutuhan peserta didik sehingga materi dapat disampaikan dengan tepat oleh guru.

Salah satu model pembelajaran yang tepat untuk meningkatkan hasil belajar serta aktivitas belajar adalah Pembelajaran Quantum (Quantum Learning). Pembelajaran quantum merupakan pembelajaran yang dipandang sebagai metode pembelajaran ideal dimana dalam pelaksanaannya menekankan pada kerja sama yang terjalin antara guru dan peserta didik untuk mencapai tujuan pembelajaran
(Huda, 2013). Pembelajaran Quantum dapat diterapkan pada kelas tinggi karena sesuai dengan perkembangan kognitif yang dimiliki oleh peserta didik telah masuk pada tahap operasional konkret pada rentang usia 7-11 tahun. Pembelajaran Quantum (Quantum Learning) tidak menghilangkan kebiasaan belajar siswa sebelumnya melainkan untuk mengkondisikan suasana lingkungan belajar menjadi lebih nyaman dengan tujuan untuk mendorong peserta didik menjadi lebih aktif dan mengembangkan potensi yang dimiliki oleh peserta didik sehingga secara tidak langsung ikut serta dalam meningkatkan hasil belajar peserta didik.

Belajar merupakan sebuah proses yang dilakukan oleh setiap individu untuk memperoleh perubahan tingkah laku secara keseluruhan berdasarkan pengalaman yang diperoleh dari lingkungan baru di sekitarnya (Aunurrahman, 2013: 35). Sementara Siregar,, (2010: 3) menyatakan bahwa belajar merupakan suatu proses yang ada pada setiap individu dan berlangsung seumur hidup ditandai dengan ada perubahan tingkah laku yang bersifat pengetahuan (Kognitif), dan keterampilan (psikomotor) serta menyangkut nilai dan sikap (afektif). Menurut Gagne dalam 
Susanto, (2018: 2) belajar dapat dikatakan sebagai perubahan perilaku individu berdasarkan pengalaman yang dimiliki. Sementara Sudjana dalam jurnal Maisaroh, (2010) menjelaskan belajar adalah proses perubahan diri yang dimiliki seseorang menuju kearah yang lebih baik. Menurut Mintarsih (2014:62) "para ahli psikolog dan guru-guru pada umumnya memandang belajar sebagai perubahan tingkah laku, pandangan ini memisahkan pengertian yang tegas antara pengertian proses belajar". Belajar mungkin saja terjadi tanpa pembelajaran, namun pengaruh aktivitas pembelajaran dalam belajar hasilnya lebih mudah diamati.

Kusumawardani (2016) menyatakan bahwa "pembelajaran merupakan proses interaksi timbal balik antara guru dan siswa". Sedangkan Suardi, (2018:7) menyatakan bahwa pembelajaran merupakan sebuah proses pemerolehan ilmu dan pengetahuan, keterampilan serta sikap dan kepercayaan pada peserta didik yang diberikan oleh guru. Sementara Meriani, (2014) pembelajaran merupakan suatu proses yang tidak mudah dan bukan hanya dengan menyerap informasi yang diberikan oleh guru namun juga memiliki serangkaian kegiatan serta tindakan lainnya dengan tujuan untuk mendapat hasil belajar yang lebih baik. Sejalan dengan Gagne (Sutrisno, 2016) "Pembelajaran merupakan kegiatan yang secara sistematis dirancang dan dilaksanakan dengan prosedur tertentu untuk melakukan pendekatan sebaik mungkin untuk tercapainya tujuan belajar yang ditetapkan" yang dikutip oleh.

Pembelajaran yang efektif ditandai dengan terjadinya proses belajar dalam diri peserta didik. Suardi, (2018:16) menyatakan bahwa proses belajar terjadi pada saat individu dihadapkan pada situasi baru yang mengharuskannya untuk dapat menyesuaikan diri dengan lingkungan sekitar. Proses penyesuaian diri perlu diciptakan dan dikondisikan oleh guru di dalam kelas. Kegiatan ini disebut sebagai pengkondisian proses belajar. Pengkondisian belajar merupakan upaya yang difasilitasi guru di dalam kelas agar interaksi peserta didik dapat berlangsung secara berproses aktif, kreatif, efektif dan menyenangkan (PAKEM). Manurung (2017) menyatakan dalam penelitiannya bahwa pembelajaran PAKEM berpengaruh terhadap hasil belajar. Maka pembelajaran PAKEM menjadi tujuan dari pengkondisian belajar, pengkondisian belajar merupakan upaya yang dilakukan guru untuk dapat menstimulus dan 
Analisis Pengaruh Pembelajaran Quantum...

memotivasi peserta didik untuk mampu memahami apa yang sedang dipelajarinya dengan suasana pembelajaran yang nyaman sehingga hubungan sosial dan sikap kerjasama antara guru dan peserta didik dapat terjalin dengan baik sehingga proses belajar jadi lebih bermakna. Menurut Ratnawati (2017) dalam penelitian yang telah dilakukan mengatakan bahwa proses belajar yang berjalan secara alami dapat mengoptimalkan proses belajar tersebut karna pembelajaran berlangsung dengan kondisi bebas dari stress.

Berdasarkan teori yang telah diuraikan diatas dapat disimpulkan bahwa proses belajar adalah suatu upaya yang dilakukan guru dengan menciptakan situasi baru agar peserta didik dapat menyesuaikan diri dengan lingkungan sekitar dengan karakteristik: (a). Bebas stress (b). Rasa nyaman, (c). Hubungan sosial, (d). Sikap kerjasama.

Perubahan tingkah laku yang terjadi selama proses belajar dapat dikatakan sebagai hasil belajar. Menurut Syaodih (2011: 179), Hasil belajar bukan hanya pengetahuan yang dimiliki tetapi juga meliputi kecakapan, kemampuan serta keterampilanan dalam menganalisis dan memecahkan masalah serta menyusun rencana yang diikuti dengan pembagian kerja sehingga hasil dari kegiatan belajar tersebut mendapatkan penilaian. Sejalan dengan Maisaroh (2010) yang mengatakan bahwa hasil belajar adalah pemerolehan hasil yang didapatkan melalui proses pembelajaran dengan melakukan sebuah penilaian berupa tes yang mencakup kognitif, afektif dan psikomotorik seseorang. Sedangkan menurut Ratnawati (2017), "Hasil belajar merupakan perubahan tingkah laku yang dapat diamati dan diukur dalam bentuk kompetensi yang terdiri dari pengetahuan, sikap dan keterampilan. Perubahan tersebut dapat diartikan sebagai terjadinya peningkatan dan pengembangan yang lebih baik sebelumnya yang tidak tahu menjadi tahu, dari yang tidak mampu menjadi mampu."

Menurut Suprihatiningsih (2016: 63) menyatakan bahwa hasil belajar merupakan pemahaman yang dimiliki oleh peserta didik melalui proses pembelajaran yang diberikan oleh guru dengan menghasilkan kemampuan yang dapat diterapkan dalam kehidupan serta lingkungan sekitar. Sependapat dengan Yanuarti \& Sobandi, (2016) hasil belajar merupakan perubahan tingkah laku peserta didik dalam memenuhi tahapan dalam kompetensi dasar berdasarkan 
pengalaman belajar dan kemampuan yang dimiliki peserta didik. Gagne dalam Dahar, Ratna Wilis (2011:118) mengungkapan bahwa terdapat lima kemampuan yang dapat dikatakan sebagai hasil belajar diantaranya terdiri dari keterampilan intelektual, strategi kognitif, sikap, informasi verbal, keterampilan motorik yang dimiliki oleh masing-masing individu dalam kondisi yang berbeda. Sedangkan Sutrisno \& Siswanto (2016) mengungkapkan bahwa; "hasil belajar merupakan tindakkan evaluasi yang dapat mengungkap aspek proses berpikir (cognitive domain), aspek kejiwaan yaitu nilai atau sikap (affective domain) dan aspek keterampilan (psychomotor domain) yang melekat pada setiap individu peserta didik."

Berdasarkan teori yang telah diuraikan diatas dapat di sintesiskan bahwa hasil belajar merupakan kemampuan yang dimiliki peserta didik sebagai hasil perubahan perilaku dari proses pembelajaran yang merupakan peningkatan aspek:(a). Pengetahuan (kognitif),(b). Keterampilan (psikomotor), (c). Sikap (efektif). Dalam penelitian ini yang menjadi perhatian peneliti adalah ranah kognitif dikarenakan variabel yang diukur alam penelitian ini adalah hasil belajar, yaitu pemahaman siswa setelah mendapatkan perlakuan melalui model pembelajaran yang diterapkan selama pelaksanaan penelitian. Selain itu juga mempertimbangkan waktu serta tujuan penelitian. Hasil belajar dinilai berdasarkan hasil perbandingan pretest dengan posttest.

Pembelajaran quantum merupakan konsep pembelajaran yang bertujuan untuk meningkatkan proses pembelajaran yang dilaksanakan baik individu maupun kelompok. Dalam proses pembelajaran pemilihan dan pengunaan model pembelajaran yang tepat dapat membantu peserta didik dalam memahami materi yang diberikan serta menciptakan suasana belajar yang kondusif. Salah satu model pembelajaran yang dapat diterapkan adalah model pembelajaran quantum, seperti yang diungkapkan oleh Kusumawardani (2016) bahwa model pembelajaran Quantum adalah salah satu model pembelajaran yang mengutamakan pada suasana belajar yang menyenangkan untuk peserta didik di kelas. Sedangkan menurut Ketut Susiani, Dantes, \& Tika (2013) model pembelajaran Quantum merupakan salah satu model pembelajaran yang menekankan pada pentingnya interaksi yang terjalin antara sesama peserta didik, begitupula dengan 
Analisis Pengaruh Pembelajaran Quantum...

hubungan yang terjalin antara peserta didik dengan guru. sependapat dengan Huda, Marhaeni, \& Suastra (2013) yang mengatakan bahwa model pembelajaran quantum dapat dikatakan model pembelajaran yang ideal dengan menekankan pada sikap kerja sama yang terjalin antara peserta didik dengan guru untuk bersama mencapai tujuan pembelajaran.

De Porter dan Mike Hernacki (2010: 49) pelaksanaan model quantum learning dalam pembelajaran lebih menekankan pada kekuatan AMBAK,"Apa Manfaatnya Bagiku" yaitu motivasi yang didapat dari pemilihan secara mental antara manfaat dan akibat-akibat suatu keputusan. Kekuatan AMBAK terdapat dalam langkah pembelajaran quantum dengan strategi TANDUR (tumbuhkan, alamai, namai, demonstrasikan, ulangi, dan rayakan).

Bobby De Poter dalam Kosasih (2013: 80) menuliskan langkah-langkah menggunakan konsep TANDUR adalah sebagai berikut: (a) Tumbuhkan, yaitu dengan memberikan apersepsi yang mampu memberikan motivasi terhadap peserta didik, (b) Alami, yaitu memberikan pengalaman secara langsung kepada peserta didik, (c) Namai, yaitu Peserta didik diminta memberikan nama materi pelajaran dan menyimpulkan konsep dari kegiatan yang telah ia lakukan,(d) Demontrasikan, yaitu dengan memberikan kesempatan kepada peserta didik mempresentasikan hasil karyanya atau hasil diskusi di depan kelas,(e) Ulangi, yaitu mengulangi atau membuat kesimpulan dari apa yang telah di pelajari untuk mengetahui sejauh mana pemahamannya terhadap materi, (f) Rayakan, yaitu dengan mengapresiasikan suatu keberhasilan dengan berbagai cara seperti reward, tepuk tangan, bernyanyi, acungan jempol, yel-yel dan lain-lain.

Menurut Porter dan Mike dalam Kusumawardani (2016) manfaat pembelajaran Quantum, yakni menumbuhkan sikap positif, memotivasi siswa dalam kegiatan pembelajaran, dapat memiliki keterampilan belajar seumur hidup, meningkatkan rasa kepercayaan diri yang dimiliki peserta didik dan sukses pada peserta didik.

Berdasarkan pengertian yang telah diuraikan diatas dapat di sintesiskan model pembelajaran quantum merupakan model pembelajaran yang ideal dengan menekankan pada penilaian terhadap: (a) pemahaman peserta didik atas manfaat mempelajari sesuatu "Apa Manfaatnya Bagiku", (b)menggunakan 
pola menumbuhkan, mengalami, menamai, mendemonstrasikan, mengulangi, dan merayakan (TANDUR). (c) menanamkan rasa kepercayaan diri, (d). Belajar dengan pengulangan.

\section{Metode}

Pendekatan penelitian ini adalah pendekatan campuran (mixed methods). dengan menggunakan desain preeksperimen. Desain pre-eksperimen penelitian ini adalah One-Group PretestPosttest, dengan dilakukan dengan dilakukan pre-test sebelum diberikan perlakuan sehingga pengaruh dari hasil perlakuan dapat diketahui lebih akurat dengan membandingkan dengan keadaan sebelum diberi perlakuan (Sugiyono, 2018: 74).

Data penilitian dianalisis menggunakan statistika deksriptif. Populasi dalam penelitian ini adalah keseluruhan siswa kelas VA SDN Joglo 04 Petang yang berjumlah 32 orang. Dengan sampel penelitian pada penelitian ini berjumlah 32. Dengan menggunakan Rumus Slovin dan taraf kesalahan 5\% akan diperoleh ukuran sampel sejumlah 30 siswa. Penelitian ini merupakan penelitian kuantitatif deksriptif. Variabel Penelitian ini terdiri dari tiga variabel, yaitu satu variabel bebas (independent variable) dan dua variabel terikat (dependent variable). Pembelajaran quantum sebagai variabel bebas $(X)$ terhadap proses belajar sebagai variabel terikat $\left(Y_{1}\right)$ dan hasil belajar sebagai variabel terikat $\left(Y_{2}\right)$. Pengaruh antara variabel bebas terhadap variabel terikat ditunjukkan dalam bentuk paradigma yang digunakan dalam penelitian ini yaitu hubungan antara $X$ dan $Y_{1}$, dan $X$ dengan $Y_{2}$ (Sugiyono, 2018:45), seperti pada Gambar 1.

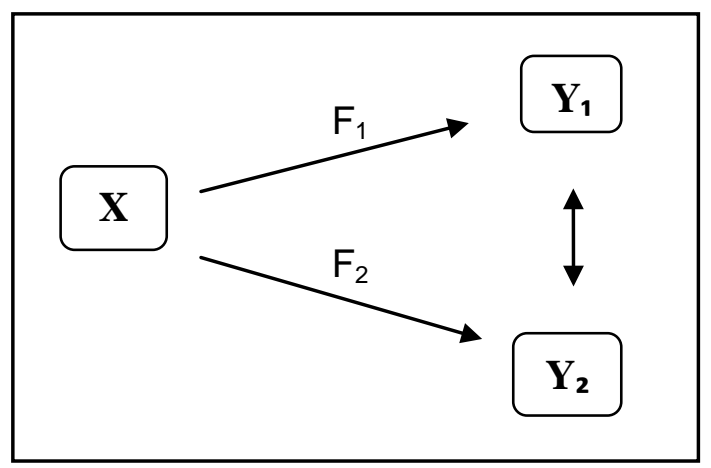

Gambar 1. Paradigma Ganda

Keterangan: $\mathrm{X}_{1}$ : Pembelajaran Quantum 
Analisis Pengaruh Pembelajaran Quantum...

$Y_{1}$ : Proses Belajar

$\mathrm{Y}_{2}$ : Hasil Belajar

Instrumen pada penelitian ini terdapat tiga instrumen, yaitu Pembelajaran Quantum (X), Proses Belajar $\left(Y_{1}\right)$, dan hasil Belajar $\left(Y_{2}\right)$. Angket (kuesioner) yang digunakan dalam instrumen penelitian disusun dengan menggunakan skala Skala Likert 4 opsi, yaitu : Sangat Setuju (SS) $=4$, Setuju $(\mathrm{S})=3$, Tidak Setuju $(\mathrm{TS})=$ 2, dan Sangat Tidak Setuju (STS) $=1$ yang digunakan pada variabel Pembelajaran Quantum (X) dan Proses Belajar $\left(Y_{1}\right)$, sementara pada variabel hasil belajar $\left(Y_{2}\right)$ diukur dengan menggunakan data hasil belajar penilaian ulangan harian mata pelajaran IPA yang dilakukan oleh guru pada saat sebelum dan sesudah penerapan pembelajaran quantum.

Untuk menguji validitas angket, peneliti menggunakan teknik analisis Product Moment dengan taraf kepercayaan 95\%. Sedangkan untuk menguji reliabilitas angket, peneliti menggunakan rumus Alpha Cronbach. Untuk mengetahui apakah data berdistribusi normal atau tidak dilakukan uji normalitas model regresi menggunakan Liliefors dengan taraf signifikan 0,05. Kemudian untuk menentukan

persamaan

regresi,dilakukan perhitungan regresi linier sederhana.

Pengujian hipotesis, dilakukan uji parsial (uji t) untuk mengetahui pengaruh masing-masing variabel bebas terhadap variabel terikat. Analisis data dilakukan menggunakan bantuan program SPSS for windows release 23 .

Hipotesis statistik yang digunakan dalam penelitian ini adalah sebagai berikut,

$\mathrm{H}_{0}: \beta=0$

$H_{1}: \beta \neq 0$

Keterangan :

Ho: Tidak adanya pengaruh pembelajaran quantum terhadap proses dan hasil belajar siswa pada mata pelajaran IPA kelas $V$ di SDN Joglo 04 $\mathrm{H}_{1}$ : Adanya pengaruh pembelajaran quantum terhadap proses dan hasil belajar siswa pada mata pelajaran IPA kelas V di SDN Joglo 04.

\section{Hasil dan Pembahasan}

Hasil perhitungan normalitas dari variabel Pembelajaran quantum terhadap proses dan hasil belajar sebelum adanya penerapan pembelajaran quantum dengan menggunakan bantuan SPSS for windows seri 23.0 seperti terlihat pada Tabel 1. 
Tabel 1. Uji Normalitas Liliefors

\begin{tabular}{|c|c|c|c|c|c|}
\hline \multicolumn{6}{|c|}{ One-Sample Kolmogorov-Smirnov Test } \\
\hline & & $\begin{array}{c}\text { Pembelajaran } \\
\text { Quantum }\end{array}$ & $\begin{array}{l}\text { Proses } \\
\text { Belajar }\end{array}$ & Prestest & Posttest \\
\hline $\mathrm{N}$ & & 30 & 30 & 30 & 30 \\
\hline \multirow{2}{*}{$\begin{array}{l}\text { Normal } \\
\text { Parameters }\end{array}$} & Mean & 71,93 & 77,80 & 69,33 & 80,30 \\
\hline & $\begin{array}{l}\text { Std. } \\
\text { Deviation }\end{array}$ & 7,182 & 7,770 & 6,161 & 7,711 \\
\hline Most Extreme & Absolute & 108 & 125 & 157 & 117 \\
\hline Differences & $\begin{array}{l}\text { Positive } \\
\text { Neqative }\end{array}$ & $\begin{array}{r}, 108 \\
-.066\end{array}$ & $\begin{array}{r}, 125 \\
-.079\end{array}$ & $\begin{array}{l}, 157 \\
-087\end{array}$ & $\begin{array}{l}, 117 \\
-.096\end{array}$ \\
\hline $\begin{array}{l}\text { Test Statistic } \\
\text { Asymp. Sig. (2 }\end{array}$ & tailed) & $\begin{array}{l}108 \\
, 200^{c, d}\end{array}$ & $\begin{array}{l}, 125 \\
, 200^{\mathrm{c}, \mathrm{d}}\end{array}$ & $\begin{array}{l}157 \\
, 057^{c}\end{array}$ & $\begin{array}{l}117 \\
, 200^{c, d}\end{array}$ \\
\hline
\end{tabular}

Perhitungan uji normalitas menggunakan uji Liliefors. Dari Tabel 1, Uji Normalitas Liliefors di atas, diperoleh nilai signifikansi pada pembelajaran quantum sebesar 0,200 , nilai signifikansi pada proses belajar sebesar 0,200 , nilai signifikansi pada hasil belajar pretest sebesar 0,57, dan nilai signifikansi pada hasil belajar posttest sebesar 0,200. Dari masing-masing nilai signifikansi yang dimiliki setiap variabel memiliki nilai signifikansi $>0,05$, artinya data berdistiribusi normal, maka dapat dinyatakan $\mathrm{H}_{\mathrm{o}}$ diterima yang berarti data berdistribusi normal. Adapun analisis regresi linear sederhana ini untuk menguji pengaruh pembelajaran quantum terhadap proses dan hasil belajar siswa. Penyelesaian uji regresi linear sederhana dengan menggunakan bantuan Program SPSS for windows seri 23.0. Adapun hasil perhitungannya dapat dilihat pada Tabel 2 dan Tabel 3.

Tabel 2. Persamaan Regresi Proses Belajar Dengan Pembelajaran Quantum Coefficients $^{a}$

\begin{tabular}{|c|c|c|c|c|c|c|}
\hline & \multirow[t]{2}{*}{ Model } & \multicolumn{2}{|c|}{$\begin{array}{l}\text { Unstandardized } \\
\text { Coefficients }\end{array}$} & $\begin{array}{c}\text { Standardize } \\
d \\
\text { Coefficients }\end{array}$ & \multirow[t]{2}{*}{$t$} & \multirow[t]{2}{*}{ Sig. } \\
\hline & & $B$ & Std. Error & Beta & & \\
\hline \multirow[t]{2}{*}{1} & (Constant) & 29,972 & 11,657 & & 2,571 & ,016 \\
\hline & $\begin{array}{l}\text { Pembelajaran } \\
\text { Quantum }\end{array}$ & ,665 & 161 & ,615 & 4,123 & ,000 \\
\hline
\end{tabular}

a. Dependent Variable: Proses Belajar 
Analisis Pengaruh Pembelajaran Quantum...

Tabel 3. Persamaan Regresi Hasil Belajar Dengan Pembelajaran Quantum

\begin{tabular}{|c|c|c|c|c|c|c|}
\hline \multicolumn{7}{|c|}{ Coefficients $^{a}$} \\
\hline & \multirow[t]{2}{*}{ Model } & \multicolumn{2}{|c|}{$\begin{array}{l}\text { Unstandardized } \\
\text { Coefficients }\end{array}$} & \multirow{2}{*}{$\begin{array}{c}\begin{array}{c}\text { Standardized } \\
\text { Coefficients }\end{array} \\
\text { Beta } \\
\end{array}$} & \multirow[t]{2}{*}{$\mathrm{t}$} & \multirow[t]{2}{*}{ Sig. } \\
\hline & & $\mathrm{B}$ & Std. Error & & & \\
\hline \multirow[t]{2}{*}{ L } & (Constant) & 31,462 & 11,361 & & 2,769 & ,010 \\
\hline & $\begin{array}{l}\text { Pembelajaran } \\
\text { Ouantum }\end{array}$ & ,679 & , 157 & ,632 & 4,319 & ,000 \\
\hline
\end{tabular}

a. Dependent Variable: Hasil Belajar Posttest

Persamaaan regresi yang diperoleh adalah:

1. Dengan diberikan perlakuan $\mathrm{X}$ (Dengan Pembelajaran Quantum) maka proses belajar akan memiliki kontribusi positif sebesar 29,972, dan perlakuan satu satuan pada $X$ akan meningkatkan proses belajar 0,665 ; $Y=29,972+0,665 X$.

2. Dengan diberikan perlakuan $X$ (Dengan Pembelajaran Quantum) maka hasil belajar akan memiliki konstribusi positif sebesar 31,462, dan perlakuan satu satuan pada $X$ akan meningkatkan hasil belajar 0,$679 ; Y=31,462+0,679 X$

Dengan konstanta yang positif pada persamaan regresi diatas, menandakan bahwa proses belajar dengan metode pembelajaran quantum dapat memberikan dampak baik terhadap hasil belajar yang diperoleh peserta didik.

Hasil pengujian hipotestis uji parsial (uji t) pada penelitian ini dapat dilihat berdasarkan Tabel 4, dan Tabel 5.

Tabel 4.

Uji Parsial (Uji T) Proses Belajar Dengan Pembelajaran Quantum

\begin{tabular}{|c|c|c|c|c|c|}
\hline \multicolumn{6}{|c|}{ Coefficients $^{\mathrm{a}}$} \\
\hline \multirow[t]{2}{*}{ Model } & \multicolumn{2}{|c|}{$\begin{array}{l}\text { Unstandardized } \\
\text { Coefficients }\end{array}$} & \multirow{2}{*}{$\begin{array}{c}\text { Standardized } \\
\text { Coefficients } \\
\text { Beta }\end{array}$} & \multirow[t]{2}{*}{$\mathrm{t}$} & \multirow[t]{2}{*}{ Sig. } \\
\hline & B & Std. Error & & & \\
\hline $\begin{array}{l}\text { (Constant) } \\
\text { Pembelajaran }\end{array}$ & 29,972 & 11,657 & & 2,571 & ,016 \\
\hline $\begin{array}{l}\text { Quantum } \\
\text { Sesudah } \\
\text { Penerapan }\end{array}$ & ,665 & 161 & 615 & 4,123 & , 000 \\
\hline
\end{tabular}

a. Dependent Variable: Proses Belajar Dengan Pembelajaran Quantum 


\section{Tabel 5.}

Uji Parsial (Uji T) Hasil Belajar

\begin{tabular}{|c|c|c|c|c|c|c|c|}
\hline \multicolumn{8}{|c|}{ Paired Samples Test } \\
\hline \multicolumn{8}{|c|}{ Paired Differences } \\
\hline & \multirow[t]{2}{*}{ Mean } & $\begin{array}{c}\text { Std. } \\
\text { Deviatio } \\
n\end{array}$ & $\begin{array}{l}\text { Std. } \\
\text { Error } \\
\text { Mean }\end{array}$ & $\begin{array}{c}95 \% \\
\text { Confidence } \\
\text { Interval of the } \\
\text { Difference }\end{array}$ & \multirow[t]{2}{*}{$\mathrm{t}$} & \multirow[t]{2}{*}{ df } & \multirow[t]{2}{*}{$\begin{array}{l}\text { Sig. } \\
(2- \\
\text { tailed) }\end{array}$} \\
\hline & & & & Lower Upper & & & \\
\hline $\begin{array}{l}\text { Pair Prestest - } \\
1 \quad \text { Posttest }\end{array}$ & $-10,967$ & 8,739 & 1,596 & $-14,230-7,703$ & $-6,873$ & 29 & ,000 \\
\hline
\end{tabular}

Dasar pengambilan keputusan untuk menerima hipotesis apabila $t_{\text {hitung }}>t_{\text {tabel, }}$, dan signifikansi < 0,05. Untuk menentukan nilai $t_{\text {tabel }}$ dilakukan perhitungan sebagai berikut,

$$
\begin{aligned}
& \text { df }=\alpha: 2 ; n-k-1 \\
& \text { df }=0,05: 2 ; 30-1-1 \\
& \text { df }=0,025 ; 28
\end{aligned}
$$

Berdasarkan perhitungan di atas, diperoleh nilai $t_{\text {tabel }}$ sebesar 2,048. Dari tabel Coefficients di atas menunjukkan hasil uji t untuk pembelajaran quantum $(X)$ terhadap proses belajar $\left(Y_{1}\right)$ diperoleh $t_{\text {hitung }}=4,123>t_{\text {tabel }}=2,048$ dengan signifikansi $0,000<0,05$.

Hasil ini menunjukkan thitung signifikan, sehingga $\mathrm{H}_{\mathrm{o}}$ ditolak dan terima $\mathrm{H}_{1}$ yang artinya terdapat pengaruh positif dan signifikan antara pembelajaran quantum terhadap proses belajar peserta didik. Selanjutnya pada hasil uji t untuk pembelajaran quantum $(X)$ terhadap hasil belajar $\left(Y_{2}\right)$ diperoleh $t_{\text {hitung }}=6,873>t_{\text {tabel }}$
= 2,048 dengan signifikansi 0,000<0,05. Hasil ini menunjukkan $t_{\text {hitung signifikan }}$ sehingga $\mathrm{H}_{0}$ ditolak dan terima $\mathrm{H}_{1}$ yang artinya terdapat pengaruh positif dan signifikan antara pembelajaran quantum terhadap hasil belajar peserta didik.

\section{Simpulan dan Saran}

Berdasarkan data yang telah dianalisis, maka hasil penelitian tentang analisis pengaruh pembelajaran quantum terhadap proses dan hasil belajar mata pelajaran IPA kelas $V$ di SDN Joglo 04 petang, dapat ditarik kesimpulan yakni (1) Dalam penerapan pembelajaran quantum yang menjadi dasar dalam proses pembelajaran tersebut adalah penggunaan strategi menumbuhkan, mengalami, menamai, mendemonstrasikan, mengulangi, dan merayakan (TANDUR); (2) Pembelajaran quantum memiliki pengaruh positif terhadap proses belajar, dimana hasil 
Analisis Pengaruh Pembelajaran Quantum...

yang diperoleh $t_{\text {hitung }}$ dinyatakan signifikan sehingga $\mathrm{H}_{0}$ ditolak dan terima $\mathrm{H}_{1}$; dan (3) Pembelajaran quantum memiliki pengaruh positif terhadap hasil belajar, dimana hasil yang diperoleh $t_{\text {hitung }}$ dinyatakan signifikan sehingga $\mathrm{H}_{\mathrm{o}}$ ditolak dan terima $\mathrm{H}_{1}$.

Adapun saran yang diberikan adalah (1) Dengan penelitian ini guru diharapkan mampu menerapkan model pembelajaran quantum guna untuk menciptakan suasana proses belajar yang interaktif dan juga menyenangkan sehingga mampu meningkatkan hasil belajar peserta didik; dan (2) Bagi peneliti selanjutnya, penelitian ini dapat dilakukan kembali dengan objek penelitian yang berbeda, serta penelitian ini dapat dimanfaatkan sebagai bahan rujukan dalam melakukan penelitian yang berkaitan dengan pembelajaran quantum, proses belajar dan hasil belajar.

\section{Daftar Pustaka}

Aunurrahman. 2013. Belajar dan Pembelajaran. Bandung:ALFABETA.

Dahar, Ratna Wilis. 2011. Teori-teori Belajar \& Pembelajaran. Jakarta:Erlangga.

Huda, N., Marhaeni, A. A. I. N., \& Suastra, I. W. 2013. Dalam Pembelajarab IPA Terhadap Motivasi Belajar dan Penguasaan Konsep Siswa Kelas IV SDN 3
PANCOR. E-Journal Program Pascasarjana Universitas Pendidikan Ganesha, 3(3).

Kusumawardani, I. 2016. Penerapan Quantum Learnng Untuk Meningkatkan Motivasi. Jurnal Pendidikan Guru Sekolah Dasar Edisi 20, 20(1), 923-933.

Maisaroh, \& Rostrieningsih. 2010. Peningkatan Hasil Belajar Siswa Dengan Menggunakan Metode Pembelajaran Active Learning Tipe Quiz Team Pada Mata Pelajaran Keterampilan Dasar Komunikasi Di SMK Negeri 1 Bogor. Ekonomi \& Pendidikan, 8 nomor 2, 157-172.

Manurung, A. S. 2017. Kontribusi Model Pembelajaran Pakem Terhadap Hasil Belajar Matematika Siswa Kelas XI IPA SMA Negeri 31 Jakarta. SEJ, 7(1), 273-284.

Meriani, N. K., Darsana, I. W., \& Suardika, I. W. R. 2014. Pengaruh Model Brain Based Learning Berbantuan Media Grafis Terhadap Hasil Belajar IPS Siswa Kelas V SD Negeri Gugus Letda Kajeng Jurusan Pendidikan Guru Sekolah Dasar , FIP Universitas Pendidikan Ganesha. Mimbar PGSD Universitas Pendidikan Ganesha, 2(2), 10.

Porter, De \& Mike, 2010. Quantum Learning membiasakan belajar nyaman dan menyenangkan. Bandung:Kaifal

Ratnawati, S. 2017. Proses Penerapan Keteampilan Manajemen Kelas Dengan Senam Otak dan Pengaruhnya Terhadap Kesiapan Belajar dan Hasil Belajar Mata Kuliah Metode Penelitian 
Mahasiswa PGSD, FKIP Universitas Esa Ungguul, Jakarta. Pendidikan Guru Sekolah Dasar, 3(1), 821-829.

Siregar, Eveline dan Hartini Nara. 201). Teori Belajar dan Pembelajaran. Jakarta:Ghalia Indonesia.

Suardi, Moh. 2018. Belajar Mengajar. Yogyakarta:Deepublish.

Sugiyono. 2018. Metode Penelitian Kuantitatif. Bandung:Alfabeta.

Suprihatianingsih. 2016. Perspektif Manajemen Pembelajaran Program Keterampilan.

Yogyakarta:Deepublish.

Susanto, Ahmad. 2018. Teori belajar \& Pembelajaran di Sekolah Dasar. Jakarta: Kencana.
Susiani, K., Dantes, N., \& Tika, N. 2013. Pengaruh Model Pembelajaran Quantum Terhadap Kecerdasan Sosio-Emosional Dan Prestasi Belajar Ipa Siswa Kelas V Sd Di Banyuning. Jurnal Pendidikan Dasar, 3(1).

Sutrisno, V., \& Siswanto, B. T. 2016. Faktor-faktor Yang Mempengaruhi Hasil Belajar Siswa Pada Pembelajaran Praktik Kelistrikan Otomotif SMK di Kota Yogyakarta. Pendidikan Vokasi, 6(1), 112-119.

Yanuarti, A., \& Sobandi, A. 2016. Upaya Meningkatkan Hasil Belajar Siswa Melalui Penerapan Model Pembelajaran Quantum Teaching. Manajemen Perkantoran, 1(1), 1118. 